\title{
DESCOLA, PHILIPPE. DIVERSITÉ DES NATURES, DIVERSITÉ SES CULTURES. LES PETITES CONFERENCES. FRANCE: BAYARD ÉDITIONS, 2010
}

\author{
Renata Colbeich da Silva ${ }^{1}$
}

O presente livro trata-se de uma conferência apresentada por Philippe Descola, antropólogo herdeiro de Lévi-Strauss, ministrada em Montreuil na França, em 2010. Descola é conhecido por sua dedicação aos estudos dos modos de ser a partir da natureza na Amazônia. Desde 2000, ocupa a cadeira de antropologia da natureza no Collège de France, seguindo Françoise Héritier.

Apesar de sua não recente publicação, a versão em língua portuguesa não se encontra disponível para o acesso de estudos em antropologia. Fazendo-se necessário o compartilhamento de seu conteúdo como forma de compreensão de como os diferentes povos aprendem com aquilo que está a sua volta, a partir de suas diferenças. Os escritos, que fazem parte das pequenas coleções organizadas por Gilberte Tsai, como o caso deste, são voltados para crianças de partir de 10 anos, na tratativa de despertar o conhecimento desde cedo.

Estruturado em duas partes, a primeira referente a conferência em si, diante das aventuras antropológicas do autor no alto Amazonas, na fronteira com o Equador e Peru. Já a segunda, é caracterizada pelo debate posterior em perguntas e respostas, que trazem importantes contribuições do ponto de vista de Descola sobre a antropologia e o modo de fazer etnográfico a partir de suas experiências.

Assim, o texto inicia fazendo considerações sobre como, à primeira vista, conseguimos separar natureza e cultura. Acreditamos que a natureza é tudo aquilo que vem antes do ser humano e independe de suas ações, já a cultura, é tudo que é produzido pela ação humana, como objetos, ideias, e ainda, as instituições. Cultura e natureza estariam em oposição. A oposição, segundo Descola, seria uma categorização variada em diferentes sociedades. A exemplo do grupo étnico indígena Achuar da família dos Jivaro na Amazônia, onde humanos e não humanos possuem os mesmos direitos.

A antropologia em seu papel, faria o inventário das diferenças entre essas concepções. Quando se está em processo de imersão em um campo, muitos estranhamentos surgem, do mesmo modo, que ao retornar a sua realidade, há o estranhamento do seu lugar de natureza e cultura. Há a construção de uma bagagem que te faz refletir sobre a realidade imposta, e questionar o que aprendeu como sendo correto no modo de ver as coisas.

No contexto em que Philippe Descola se encontrava junto aos Achuar, dentre as percepções que elencavam funções de caça para os homens e coleta para as mulheres, as dificuldades de aproximação com a língua local e os horários estipulados para acordar e recolher-se. A hora de acordar era às três ou quatro horas da manhã, o recolher-se aproximadamente, as 20 horas. Ao se levantarem de seus aposentos de descanso, reuniam-se e decidiam o que faziam durante o dia de acordo com seus sonhos.

\footnotetext{
${ }^{1}$ Aluna do Programa de Pós-Graduação em Ciências Sociais, nível doutorado, da Universidade Federal de Santa Maria (UFSM). Vinculada ao Grupo de Pesquisa Tuna - Gênero, Educação e Diferença da Universidade Federal do Pampa (Unipampa/Uruguaiana). Contato: rcolbeich@gmail.com
} 
As interpretações dos sonhos eram de extrema importância dentro dos acordos locais que se estruturavam. Sonhar com peixe indicava boa pesca, mas outros sonhos também indicavam proibições. Plantas e animais poderiam assumir formas humanas nos sonhos, assim como ao inverso. Havia compreensão que a humanidade era só uma aparência de obrigações estabelecidas que regem o bem viver.

Há na primeira parte do livro, a referência a outros povos e suas ligações com natureza e cultura, como no caso dos indígenas Cry no norte de Quebec, suas relações com a morte a caça. Estar morto é apenas uma aparência e quando uma animal se torna caça, para a população poder se alimentar, é mais que um alimento, mas um simbolismo de generosidade do mesmo para com aquele que o caçou.

Entre os Aborígenes, grupo totalmente diferente dos Cry e dos Achuar, há uma relação totêmica entre humanos e não humanos. A partir de características físicas e de temperamento, semelhanças são estabelecidas. Cada animal é uma espécie totêmica e um protótipo, um modele inserido para germinar. Ao contrário dos Achuar, os Aborígenes não veem os animais e plantas como pessoas, e a caça é permitida mesmo que o animal abatido seja o próprio totem do caçador. Acreditam que depois o animal reencarnará, e a proteção que ele dá aos campões e a fonte de vida vem de um lugar sagrado que não é santificado. Aqui há uma relação de comparação a natureza e cultura, mas que se coloca diferente dos Achuar.

$\mathrm{O}$ autor frisa que há a necessidade de quando formos falar em natureza, que se possa compreender o ambiente em que está sendo dada. Há o costume de ver o mundo por partes e nunca pelo todo. Deste modo, seria necessário perceber como os sujeitos estão inseridos e seus sentimentos a partir de toda a composição ao seu redor. Descola afirma que o maior problema do ser humano sempre foi de pensar que possui a natureza. Há uma exploração demasiada em que a cada dia, se paga maior preço. Apesar de outros povos serem diferentes, não significa que estejam longe de evitar um desastre.

Concluindo a primeira sessão, o autor coloca o estudo com os Achuar como uma ironia, onde o antropólogo, dispõem sua própria crença em contraponto a do outro. A antropologia neste sentido, nos mostra que estamos presos numa condição humana diferente dos demais povos do mundo. Cada vez mais precisamos investigar as maneiras originais de se habitar a terra. A condição humana de cada uma destas vem sendo mostrada pela antropologia como uma condição de trabalho eterno. Há vários presentes dentro do momento em que vivemos, e antropologia já nos mostrou muitas formas de viver juntos, somos nós que não nos permitimos outras formas.

A segunda parte do livro, "questões/respostas", é composta de questionamentos e seus respectivos comentários. A complexidade dos itens, são resumidamente elaborados a partir daqui, para que de forma simples, haja a compreensão das demais colocações de Philippe Descola presentes nesta pequena conferência. A primeira pergunta diz respeito ao que são as diferentes condições humanas. $\mathrm{O}$ autor afirma que são maneiras de viver junto, como se casar, compreender a morte, nascimento, doenças, formas de cooperar para levantar recurso, estabelecer autoridade. O antropólogo faz um inventário desses costumes a partir da etnografia diante do compartilhamento da vida cotidiana pela observação participante.

Logo em seguida, questiona-se a diferença exata entre um etnólogo e antropólogo. A resposta vem ressaltando a antropologia como a ciência, mas que há três fases distintas. A etnografia seria o primeiro passo, como o conviver, interpretar, escrever. Etnologia é a maneira de fazer comparações em escala local, há a generalização um pouco maior das coisas a partir das informações coletadas pela etnografia. Tudo isso resulta em antropologia.

A terceira interrogação, diz respeito ao homem ocidental e as mudanças diferenciadas entre estes e os Aborígenes ou os Achuar. Para isto, Descola não encontra uma resposta simples. Sugere a partir de exemplos que as pessoas não caminharam de maneira igual durante o percurso da história. A diversidade era vista em níveis de evolução e atualmente pode-se considerar que há diferentes forma de desenvolvi- 
mento, todos dentro de sistemas complexos de regras que garantem a união dos povos. O que aconteceu foi que o homem ocidental, pela colonização, tentou implementar sua regra no outro, muitas vezes a força.

Como é o contato do antropólogo com as sociedades que visitam? Como os povos veem os antropólogos lá? Será que há o questionamento da cultura do antropólogo por eles? São indagações da quarta colocação. Aqui há a exaltação dos Achuar como uma etnia diferenciada pelo seu pouco contato com o mundo para além da sua fronteira étnica, mas que as situações variam muito dependendo da sociedade na qual se está indo trabalhar. A maior parte do tempo é respondendo perguntas e pouco as fazendo. Um antropólogo para ser bom, pára de fazer perguntas e passa apenas a ouvir.

$\mathrm{Na}$ quinta pergunta, a relação da antropologia e sua análise científica a partir da visão de outras ciências duras. Para isso, Descola diz não duvidar da ciência em questão, afinal, ele próprio é um cientista e respeita as regras do método científico. Ele diz pensar numa confusão entre ciência e cosmologia, que a ciência surge desta, mas que não é um produto da atividade científica em si. A ciência ajuda ver o mundo, mas que nela ainda há muitos erros. Na antropologia rever esses erros se faz como uma constante.

No sexto, o questionar sobre a abertura dos povos isolados e possibilidade de acabar com sua diferença e riquezas. Referindo-se a pergunta como um clássico, o autor afirma que a possibilidade sempre é existente. Devemos respeitar as visões de mundo dos povos indígenas para que isso seja um primeiro passo para preservação e não impor nossas categorias. Como exemplo, Descola usa a ideia da floresta amazônica como pulmão do mundo, que para os indígenas, não faz muito sentido, mas acabam incorporando a noção ambientalista como uma forma de defender-se. Para o indígena este não passa de um discurso genérico que impede de tornar sua noção de preservar para ter o que comer e onde morar como principal.

Qual é o papel da antropologia em sociedades ocidentais? Questionou a sétima interrogação. O antropólogo francês ressalta que as ciências sociais são um único bloco de diferentes abordagens e que há distinguidos modos de se pensar a vida das pessoas e suas comunidades. Cada vez mais o papel da antropologia e dos antropólogos se faz essencial para tentar compreender melhor todas as facetas do mundo em que vivemos.

A oitava pergunta fala sobre a antropologia ser uma forma de limpar o mundo ocidental. A afirmativa para isso é posta tendo a justificativa a partir da eficiência europeia em colonizar e curiosidade para todas as formas de diferenças. Para Descola, a antropologia é filha da expansão colonial. Os Achuar tinham muitas perguntas sobre a minha sociedade. A oportunidade entre eles, fez com que fosse permitido sanar muito de suas curiosidades a partir da inserção local pelo antropólogo.

A nona, diz respeito aos questionamentos por parte dos indígenas. Há um gasto de tempo bastante relevante em relação a isso segundo o autor. Porém, há uma grande dificuldade na compreensão das respostas, o que chamamos de mal-entendido cultural. Muitas vezes nós não entendemos a pergunta e acabamos respondendo outra coisa diferente do que havia sido colocado em questão.

A última pergunta, situada em colocações sobre a antropologia ser uma disciplina fruto do colonialismo e a referência desta não estar presente na China, por citação de Descola, há o questionamento de como esta é no Japão. O autor afirma que em quase mesma medida a antropologia surge no Japão tardiamente, pelo fato do país manter-se fechado por muito tempo e as elites terem adotados muitos hábitos europeus. $\mathrm{Na}$ China poucos estrangeiros são autorizados a entrar e fazer antropologia, muitos são homens e o estudo de padrões chineses, como parentesco ficam de fora dos estudos.

Em diferentes exemplos, Philippe Descola em sua conferência aborda formas de pensar a natureza e a cultura diante animismo e a percepção que cada espécie é única, pelo totemismo e sua capacidade moral definida entre homens e animais, pelo naturalismo e a discernimento eurocêntrico de que humanos são superiores e por analogismo, onde sociedades se agrupam por suas qualidades em comum. Evidencia-se ainda a partir do que se pode tirar como análise da segunda parte do livro a constante em antropologia 
do precisar se justificar para poder trabalhar. Há sempre um desconforto pelo olhar da ciência e do outro diante do conjunto do fazer antropológico, sempre necessitando de explicações e exemplos comparativos. Diferentes naturezas e diferentes culturas trazem consigo o pensar experiências de vidas e o agir sobre um mundo que está dissociado a metades. Elas apesar de existirem, são complementares.

\section{Referências}

DESCOLA, Philippe. Diversité des Natures, Diversité ses Cultures. Les petites Conferences. France: Bayard Éditions, 2010.

Recebido em 20/06/2020

Aceito em 30/06/2020 